Original article

\title{
Efek pemberian $\alpha$-tokoferol terhadap jumlah sel spermatogenik dan sel Leydig pada tikus putih (Rattus norvegicus) yang dipapar 2,3,7,8 Tetrachlorodibenzo-p-dioxin
}

\section{Effect of $\alpha$-tocopherol on spermatogenic and Leydig cell counts of white rats (Rattus norvegicus) exposed to 2,3,7,8-Tetrachlorodibenzo-p-dioxin}

\author{
Ainun Machmudia ${ }^{1}$, Hana Eliyani ${ }^{2} \oplus$, Widjiati Widjiati² ${ }^{\circledR}$, Wurlina Wurlina ${ }^{3 *}$ \\ ${ }^{1}$ Faculty of Veterinary Medicine, ${ }^{2}$ Division of Veterinary Anatomy, ${ }^{3}$ Division of Veterinary \\ Reproduction, Faculty of Veterinary Medicine, Universitas Airlangga \\ *Corresponding author, e-mail: wurlina@fkh.unair.ac.id \\ Open access under CC BY - SA license, DOI: 10.20473/ovz.v10i3.2021.72-80 \\ Received September 11 2021, Revised September 27 2021, Accepted November 212021 \\ Published online December 12021
}

\begin{abstract}
This research aimed to determine the effect of $\alpha$-tocopherol on the count of spermatogenic and Leydig cells in rats (Rattus norvegicus) exposed to 2,3,7,8 tetrachlorodibenzo-p-dioxin (dioxin). Dioxin is an endocrine-disrupting agent that adversely affects reproductive health, while $\alpha$-tocopherol maintains fertility. This research used 25 rats aged 10-12 weeks weighing 150-200 grams. Rats were divided into five groups (K, P0, P1, P2 and P3). The K (control group) was administered with corn oil $1 \mathrm{ml} /$ day. P0 was exposed to $700 \mathrm{ng} / \mathrm{kg} /$ day dioxin. P1, P2 and P3 was exposed to dioxin at a dose of $700 \mathrm{ng} / \mathrm{kg} / \mathrm{day}$ and administered with $\alpha$-tocopherol at a dose of 77,140 and $259 \mathrm{mg} / \mathrm{kg} / \mathrm{day}$ respectively. Dioxin exposure, corn oil and $\alpha$-tocopherol administration were conducted orally for 20 days. On day-21, all rats were sacrificed for histological slides preparation of testicles with hematoxylin-eosin staining. Data were analyzed with analysis of variance and continued with the Duncan test. The results indicated that exposure to dioxin caused a decrease in the number of spermatogenic and Leydig cells. The administration of $\alpha$-tocopherol at a dose of $140 \mathrm{mg} / \mathrm{kg} / \mathrm{day}$ eliminated the effect of reducing the number of spermatogenic and Leydig cells caused by exposure to dioxin. The conclusion was the administration of $\alpha$-tocopherol at $140 \mathrm{mg} / \mathrm{kg} / \mathrm{day}$ was effective in maintaining the number of spermatogenic and Leydig cells in rats (Rattus norvegicus) exposed to 2,3,7,8 tetrachlorodibenzo-p-dioxin.
\end{abstract}

Keywords: $\alpha$-tocopherol, dioxin, interstitial cells, reproductive health, spermatogenic cell

\section{PENDAHULUAN}

Senyawa 2,3,7,8-Tetrachlorodibenzo-pdioxin (TCDD) adalah zat kimia paling berbahaya yang diketahui manusia. Senyawa TCDD merupakan produk sampingan dari proses pembakaran sampah, proses produksi pestisida, pembakaran pada proses produksi baja, dan air buangan industri terutama industri kertas yang menggunakan khlor sebagai pemutih. Selain itu sumber dioksin juga berasal dari alam yaitu kebakaran hutan dan aktivitas gunung berapi (Zubair dan Adrees, 2019). Pencemaran TCDD merupakan masalah global karena karakteristik persistent organic pollutant (POPs) yang toksik dan mudah menyebar (Guo et al., 2019). Molekul TCDD bersifat lipofilik, memiliki tingkat metabolisme dan ekskresi yang rendah, sehingga cenderung terakumulasi dalam tubuh (Yin et al., 2012). Paparan lingkungan terhadap TCDD seringkali tidak dapat dihindari bagi manusia sebagai pemuncak rantai makanan. 
Lebih dari $90 \%$ manusia terpapar oleh TCDD adalah melalui makanan, terutama daging dan produk susu, ikan dan kerang, yang selanjutnya terakumulasi dalam lemak tubuh (Perucatti et al., 2016).

Paparan TCDD menyebabkan stres oksidatif yang disebabkan oleh Reactive Oxygen Species (ROS) (Zhou et al., 2017). Molekul ROS cenderung menarik elektron dari molekul penting sekitarnya. Pada konsentrasi fisiologis, ROS bertindak sebagai mediator molekuler dari jalur transduksi sinyal yang terlibat dalam regulasi sumbu hipothalamus-hipofisis-gonad, spermatogenesis dan steroidogenesis, memicu perubahan morfologi pematangan spermatozoa (pemadatan DNA dan pembentukan ekor spermatozoa). Selanjutnya, ROS juga berperan penting pada proses kapasitasi, hiperaktivasi, reaksi akrosom dan fusi spermatozoa-oosit. Sebaliknya, stres oksidatif terjadi ketika konsentrasi ROS lebih tinggi daripada antioksidan endogen (Baskaran et al., 2019). Paparan ROS yang berlebihan menyebabkan kerusakan oksidatif pada protein, asam nukleat, asam lemak tak jenuh ganda pada membran sel, termasuk pada proses spermatogenesis (Amorini et al., 2021).

Secara fisiologis ROS dapat dinetralisir oleh antioksidan endogen. Antioksidan endogen diklasifikasikan menjadi antioksidan enzimatik dan non-enzimatik. Antioksidan enzimatik termasuk superoksida dismutase (SOD), katalase (CAT) dan glutathione peroksidase (GPx). Antioksidan non-enzimatik termasuk vitamin (A, C dan E), koenzim Q10, glutathione, $\beta$ karoten, serta selenium dan seng yang bertindak sebagai kofaktor enzim antioksidan (Baskaran et al., 2019). Faktor lingkungan seperti polutan TCDD, dapat menurunkan kapasitas antioksidan endogen. Oleh karena itu penggunaan antioksidan diharapkan dapat melawan stres oksidatif yang diinduksi radikal bebas sehingga dapat meningkatkan spermatogenesis (Asadi et al., 2017). Salah satu antioksidan yang larut dalam lemak adalah vitamin E. Senyawa $\alpha$ tokoferol pada vitamin $\mathrm{E}$ dapat mencegah terikatnya TCDD dengan reseptor AhR (Aryl hydrocarbon Receptor) yang terdapat di sitoplasma sel (Dietrich, 2016). Alfa-tokoferol adalah antioksidan eksogen yang dapat memutus reaksi berantai radikal untuk menghambat ROS dan stres oksidatif. Pemberian $\alpha$-tokoferol pada tikus di bawah stres oksidatif dapat secara signifikan mengurangi kadar Malondialdehid (MDA), menormalkan epithel tubulus seminiferus (Walker, 2009) dan meningkatkan fungsi endokrin reproduksi (Yin et al., 2012).

Penelitian untuk menemukan solusi paparan TCDD pada kesuburan pria perlu dilakukan pada hewan coba untuk kesehatan dan kesejahteraan manusia. Penelitian sebelumnya membuktikan bahwa $\alpha$-tokoferol dapat mengembalikan diameter tubulus seminiferus dan ketebalan epitel tubulus seminiferus pada tikus karena paparan dioksin (Wurlina et al., 2021). Penelitian ini bertujuan untuk mengetahui pemulihan fungsi testis berdasarkan jumlah sel spermatogenik dan sel Leydig pada tikus (Rattus norvegicus) sebagai model.

\section{METODE}

Prosedur penelitian telah disetujui oleh Komite Etik Penelitian pada Hewan Coba, Universitas Airlangga, No 267/HRECC.FDRM/ VI/2020.

\section{Dosis TCDD dan $\alpha$-tokoferol}

Penelitian ini menggunakan dosis tunggal 2,3,7,8 - tetrachlorodibenzo-p-dioxin (2,3,7,8TCDD) (Sigma 48599), berdasarkan penelitian sebelumnya yaitu $700 \mathrm{ng} / \mathrm{kg} \mathrm{BB} /$ hari. Sedangkan dosis $\alpha$-tokoferol (Sigma Aldrich Singapore) adalah 77, 140, dan $259 \mathrm{mg} / \mathrm{kgBB} /$ hari. Minyak jagung (corn oil) (Mazol® - Codaa Switzerland AG) digunakan sebagai pelarut untuk TCDD dan $\alpha$-tokoferol (Wurlina et al., 2021).

\section{Perlakuan pada hewan coba}

Tikus putih (Rattus norvegicus) jantan galur Wistar berumur 10-12 minggu sebanyak 25 ekor dibagi menjadi lima kelompok perlakuan. Kontrol (K) yaitu kelompok tikus yang hanya diberi minyak jagung (corn oil) $1 \mathrm{ml} / \mathrm{hari}$, kontrol perlakuan (P0) yaitu kelompok tikus yang diberi TCDD $700 \mathrm{ng} / \mathrm{kgBB} /$ hari, perlakuan 1 (P1) yaitu kelompok tikus yang diberi TCDD $700 \mathrm{ng} / \mathrm{kgBB} / \mathrm{hari}$ dan $\alpha$-tokoferol 77 $\mathrm{mg} / \mathrm{kgBB} /$ hari, perlakuan 2 (P2) yaitu kelompok tikus yang diberi TCDD $700 \mathrm{ng} / \mathrm{kgBB} / \mathrm{hari}$ dan $\alpha$-tokoferol $140 \mathrm{mg} / \mathrm{kgBB} / \mathrm{hari}$, dan perlakuan 3 (P3) yaitu kelompok tikus yang diberi TCDD 
$700 \mathrm{ng} / \mathrm{kgBB} / \mathrm{hari}$ dan $\alpha$-tokoferol 259 $\mathrm{mg} / \mathrm{kgBB} / \mathrm{hari}$.

Tikus dipelihara pada kandang laboratorium hewan coba, dengan pemberian pakan sekali sehari. Pemberian minyak jagung pada kelompok $\mathrm{K}$ serta pemberian TCDD pada kelompok P0, P1, P2, dan P3 dimulai pukul 09.00, dilanjutkan dengan pemberian $\alpha$ tokoferol pada kelompok P1, P2 dan P3 empat jam kemudian. Pemberian minyak jagung, TCDD dan $\alpha$-tokoferol pada tikus-tikus percobaan dilakukan per oral menggunakan sonde lambung selama 20 hari.

Pada hari ke-21 tikus dikorbankan dengan cara dislokasi serviks, dengan pemberian Ketamin 0,1 mg/BB sebelumnya. Tikus yang telah dikorbankan diletakkan di atas meja bedah dengan posisi rebah dorsal kemudian masingmasing anggota gerak difiksasi. Selanjutnya abdomen bagian bawah dijepit menggunakan pinset kemudian diangkat sedikit. Kulit abdomen yang terangkat digunting sampai abdomen terbuka. Testis diambil dengan mengangkat duktus deferens sampai testis benar-benar keluar dari abdomen. Selanjutnya testis dipotong dan difiksasi dalam formalin $10 \%$.

\section{Pengamatan variabel penelitian}

Penghitungan jumlah sel spermatogenik dan sel Leydig dilakukan dengan pembuatan sediaan histologis testis dengan pewarnaan hematoxylineosin (HE) (Gambar 1). Pengamatan dilakukan dengan mikroskop cahaya (Nikon Eclipse E 200, perbesaran 400x), yang dilengkapi dengan Software Optilab Viewer Versi 2.2. (Wurlina et $a l .$, 2021). Penghitungan sel-sel spermatogenik dan sel Leydig dilakukan secara acak pada lima tubulus seminiferous dan dihitung rata-ratanya (Ulfana et al., 2015).

Sel spermatogonium ditandai dengan inti bulat lonjong yang terletak paling dekat dengan lamina basalis. Sel spermatosit berada dalam tubulus seminiferus ditandai dengan bentuk sel yang terdapat butir-butir kromatin halus dan inti paling besar pada posisi di bidang equator. Sel spermatid berada dalam tubulus seminiferus, dapat dikenali melalui sel yang ukurannya kecil dengan daerah kromatin yang padat dan lokasinya mendekati lumen tubulus. Sel Leydig ditandai dengan letaknya berkelompok memadat pada daerah segitiga yang terbentuk oleh susunan-susunan tubulus seminiferus. Sel Leydig mempunyai inti berwarna hitam kebirubiruan dan sitoplasma berwarna merah dalam sediaan histologis pewarnaan hematoxylin-eosin (Listyorini et al., 2021).

\section{Analisis data}

Data dianalisis pada tingkat kepercayaan 95\% dengan ANOVA satu arah dilanjutkan dengan uji Duncan menggunakan program SPSS (Statistical Product and Service Solution) Versi 23.

\section{HASIL}

Paparan TCDD tanpa pemberian $\alpha$ tokoferol (kelompok P0) menghasilkan jumlah sel spermatogonium, spermatosit, spermatid, dan sel Leydig yang lebih rendah ( $p<0,05)$ dibandingkan pada tikus normal (kelompok K). Pemberian $\alpha$-tokoferol dengan dosis 77 $\mathrm{mg} / \mathrm{kgBB} / \mathrm{hari}$ pada tikus yang dipapar TCDD (kelompok P1) menyebabkan jumlah sel spermatogonium dan spermatid yang lebih tinggi ( $\mathrm{p}<0,05$ ), sedangkan jumlah sel spermatosit dan sel Leydig tidak berbeda nyata $(\mathrm{p}>0,05)$ dibandingkan dengan pada kelompok P0. Pemberian $\alpha$-tokoferol $140 \mathrm{mg} / \mathrm{kgBB} / \mathrm{hari}$ (kelompok P2) menyebabkan jumlah sel spermatogonium, spermatosit, spermatid, dan sel Leydig lebih tinggi $(\mathrm{p}<0,05)$ dibandingkan pada kelompok P0. Pada kelompok P2 jumlah sel spermatogonium lebih tinggi ( $\mathrm{p}<0,05)$, sedangkan jumlah sel spermatosit, spermatid, dan sel Leydig tidak berbeda nyata $(p>0,05)$ dibandingkan pada tikus normal (K). Pemberian $\alpha$-tokoferol $259 \mathrm{mg} / \mathrm{kgBB} /$ hari (kelompok P3) menyebabkan jumlah sel spermatogonium, spermatid, dan sel Leydig lebih tinggi $(\mathrm{p}<0,05)$, sedangkan jumlah sel spermatosit tidak berbeda nyata $(\mathrm{p}>0,05)$ dibandingkan pada tikus normal (K) (Tabel 1). 


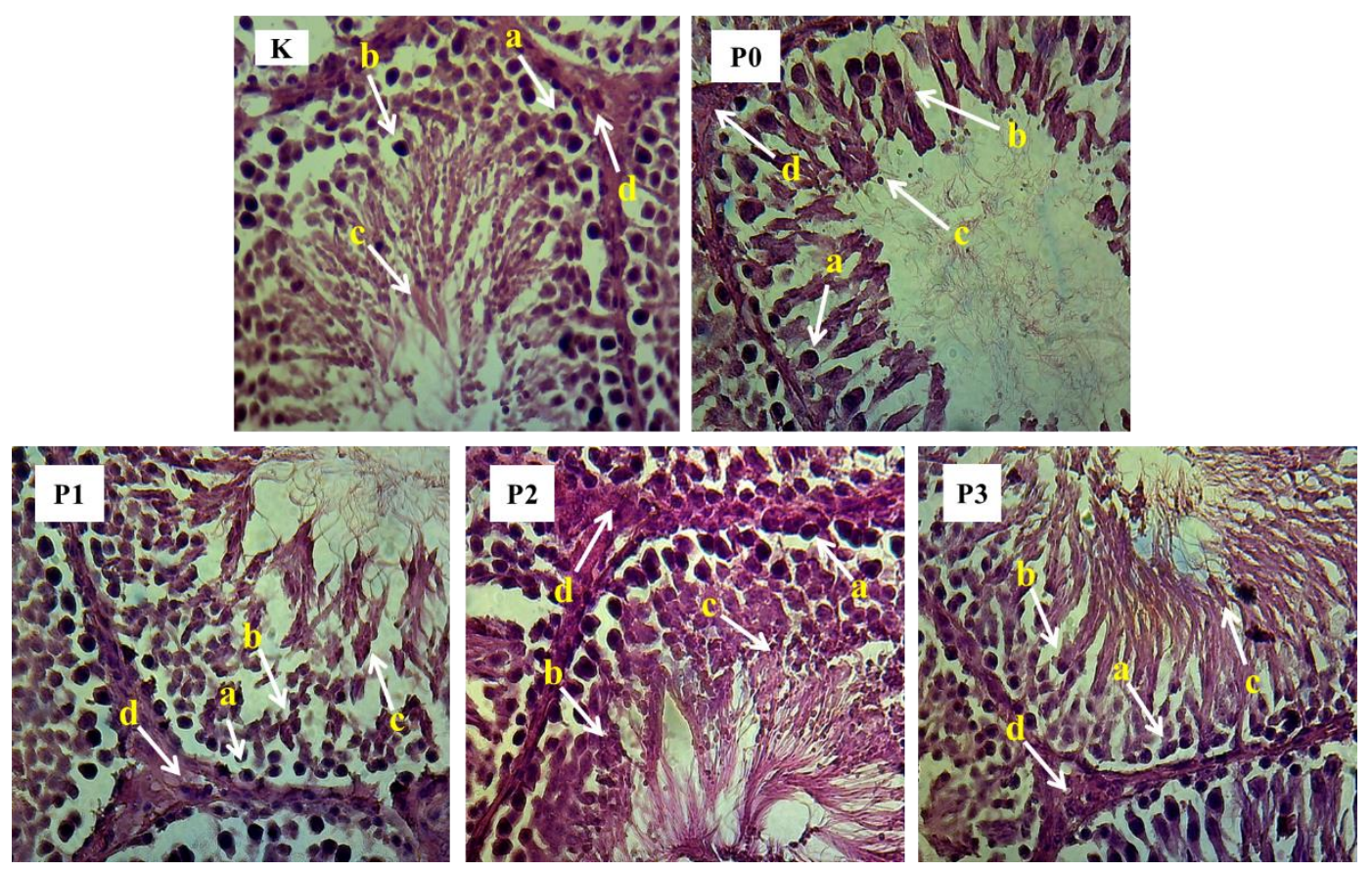

Gambar 1 Gambaran histopatologi perubahan jumlah sel spermatogenik dan sel Leydig testis tikus putih dengan pewarnaan HE; a: sel spermatogonium; b: sel spermatosit; c: sel spermatid; d: sel Leydig; K: kelompok kontrol negatif, tikus hanya diberi minyak jagung $1 \mathrm{ml} / \mathrm{hari}$; P0: kelompok kontrol positif, tikus diberi TCDD $700 \mathrm{ng} / \mathrm{kgBB} / \mathrm{hari}$; P1, P2, P3: tikus yang diberi TCDD 700 $\mathrm{ng} / \mathrm{kgBB} /$ hari dan $\alpha$-tokoferol masing-masing 77, 140 dan $259 \mathrm{mg} / \mathrm{kgBB} / \mathrm{hari}$; perlakuan per oral sekali per hari selama 20 hari; Nikon Eclipse E 200, perbesaran 400x dilengkapi dengan Software Optilab Viewer Versi 2.2.

Tabel 1 Jumlah (rata-rata \pm simpangan baku) sel spermatogenik dan sel Leydig tikus putih yang dipapar senyawa 2,3,7,8-Tetrachlorodibenzo-p-dioxin (TCDD) dan diberi $\alpha$-tokoferol

\begin{tabular}{ccccc}
\hline & spermatogonium & spermatosit & spermatid & sel Leydig \\
\hline K & $69,80 \pm 2,16^{\mathrm{c}}$ & $124,00 \pm 30,32^{\mathrm{b}}$ & $56,20 \pm 19,55^{\mathrm{b}}$ & $16,00 \pm 2,23^{\mathrm{b}}$ \\
P0 & $47,40 \pm 4,03^{\mathrm{a}}$ & $71,80 \pm 7,79^{\mathrm{a}}$ & $25,60 \pm 2,70^{\mathrm{a}}$ & $10,60 \pm 2,19^{\mathrm{a}}$ \\
P1 & $57,40 \pm 3,43^{\mathrm{b}}$ & $90,80 \pm 6,26^{\mathrm{a}}$ & $44,00 \pm 10,51^{\mathrm{b}}$ & $12,20 \pm 1,78^{\mathrm{a}}$ \\
P2 & $66,40 \pm 3,05^{\mathrm{c}}$ & $120,40 \pm 12,11^{\mathrm{b}}$ & $56,00 \pm 3,00^{\mathrm{b}}$ & $17,40 \pm 2,19^{\mathrm{b}}$ \\
P3 & $85,20 \pm 9,91^{\mathrm{d}}$ & $141,80 \pm 15,38^{\mathrm{b}}$ & $89,00 \pm 19,51^{\mathrm{c}}$ & $23,80 \pm 4,65^{\mathrm{c}}$ \\
\hline
\end{tabular}

Superskrip yang berbeda dalam satu kolom menunjukkan perbedaan yang nyata $(\mathrm{p}<0,05)$; K: kelompok kontrol negatif, tikus hanya diberi minyak jagung $1 \mathrm{ml} /$ hari; P0: kelompok kontrol positif, tikus diberi TCDD $700 \mathrm{ng} / \mathrm{kgBB} / \mathrm{hari}$; P1, P2, P3: tikus yang diberi TCDD $700 \mathrm{ng} / \mathrm{kgBB} / \mathrm{hari}$ dan $\alpha$ tokoferol masing-masing 77, 140 dan $259 \mathrm{mg} / \mathrm{kgBB} /$ hari; perlakuan diberikan per oral sekali per hari selama 20 hari; ulangan $=5$.

\section{DISKUSI}

Paparan TCDD 700 ng/kgBB/hari selama 20 hari menyebabkan penurunan jumlah sel spermatogonium, spermatosit, spermatid, dan sel Leydig pada tikus normal (Tabel 1). Hasil penelitian ini sesuai dengan laporan sebelumnya bahwa paparan TCDD meningkatkan abnormalitas pada proses spermatositogenesis (Dirican dan Kalender, 2012), sehingga menyebabkan penurunan jumlah sel spermatogenik (Wati et al., 2014). Spermatogonia dan spermatosit pada tikus yang terpapar TCDD mengalami nekrosis dan pelepasan perlekatan antar sel (Yin et al., 2012).

Senyawa TCDD menyebabkan kadar 
radikal bebas lebih tinggi daripada antioksidan endogen (Ciftci et al., 2018). Mekanisme TCDD meningkatkan jumlah radikal bebas pada testis adalah melalui ikatan aryl hydrocarbon receptor (AhR) yang berikatan dengan Aryl hydrocarbon Receptor Nuclear Translocator (ARNT) (ElGerbed et al., 2015). TCDD mengikat AhR dalam sitoplasma. Ikatan kompleks antara AhR dan TCDD mengalami konformasi perubahan dan tertranslokasi ke nukleus. Selanjutnya ikatan ini akan melakukan heterodimer dengan faktor transkripsi lain, yaitu ARNT. Heterodimer ini akan berinteraksi dengan dioxin-responsive enhancer elements (DRE) yang terletak pada permukaan gen target dan mengaktifkan berbagai faktor transkripsi pada inti sel. Heterodimer AhR-ARNT menghasilkan stimulasi gen sitokrom P450 dan akibatnya meningkatkan produksi sitokrom. Sitokrom P450 merupakan enzim yang memediasi produksi ROS (Oshchepkova et al., 2020). Radikal bebas bereaksi dengan lipid yang mengandung ikatan rangkap karbon, terutama asam lemak tak jenuh ganda, mengakibatkan peroksidasi lipid (Domínguez et al., 2019). Asam lemak tak jenuh ganda dalam membran mudah menangkap elektron tidak berpasangan dari ROS (Wagner et al., 2017). Peroksidasi lipid menyebabkan dekomposisi produk hidroperoksida menjadi senyawa sitotoksik (Zielinski dan Pratt, 2017). Molekul TCDD juga mengaktifkan aryl hydrocarbon receptor (AhR) menyebabkan dimerisasi AhR dengan aryl hydrocarbon receptor nuclear translocator (ARNT), berakibat aktivasi transkripsi beberapa enzim antioksidan terhenti. Sehingga kadar antioksidan endogen semakin tidak mencukupi untuk mengimbangi produksi berlebih radikal bebas (Dietrich, 2016). Ekspresi AhR dan ARNT ditemukan pada sel spermatogonium dan sel spermatosit, sehingga penurunan jumlah sel spermatogenik mengikuti mekanisme tersebut (Yin et al., 2012). Tingkat peroksidasi lipid yang tinggi akibat paparan TCDD mengganggu spermatogenesis dengan menyebabkan kematian sel epitel germinal (Plunk dan Richards, 2017), sehingga menurunkan jumlah sel spermatogonium, spermatosit, dan spermatid (Górnicka et al., 2019).

Peroksidasi lipid akibat paparan TCDD tidak hanya terbatas pada sel-sel spermatogenik, namun juga menyebabkan kerusakan membran sel pada aksis hipothalamus-hipofisa-testis (Darbandi et al., 2018), dan sel pendukung spermatogenesis (sel Sertoli dan sel Leydig) (Górnicka et al., 2019). Spermatogenesis melibatkan interaksi hormon endokrin, parakrin dan faktor pertumbuhan, ekspresi gen dan protein (O'Donnell et al., 2017). Stres oksidatif menyebabkan terhambatnya kinerja aksis hipothalamus-hipofisis-testis, diikuti dengan terhambatnya sekresi FSH dan LH, kemudian terganggunya fungsi sel Sertoli dan apoptosis pada sel spermatogenik (Plunk dan Richards, 2017). Spermatogenesis normal tergantung pada sel Sertoli sebagai pemasok nutrisi, pemeliharaan sambungan sel, dan dukungan untuk mitosis dan meiosis sel germinal (Ni et al., 2019). Stres oksidatif juga dapat meningkatkan inflamasi testis dengan mempengaruhi sekresi sitokin proinflamasi pada sel Sertoli (Jin et al., 2018), sehingga menurunkan proliferasi sel Sertoli (Meroni et al., 2019) dan berakibat menurunnya jumlah sel spermatogenik (Wurlina et al., 2021).

Paparan senyawa TCDD dosis 700 ng/kgBB/hari selama 20 hari dapat menyebabkan penurunan jumlah sel Leydig. Peroksidasi lipid akibat paparan TCDD merusak membran sel Leydig (Górnicka et al., 2019), selanjutnya menyerang basa purin dan pyrimidin yang menyebabkan fragmentasi DNA. Molekul ROS akibat paparan TCDD juga dapat menginisiasi apoptosis dengan aktivasi enzim Caspase (Redza-Dutordoir dan Averill-Bates, 2016), sehingga menyebabkan kematian sel Leydig. Testosteron dan Follicle Stimulating Hormone (FSH) dibutuhkan untuk proses spermatogenesis (O'Donnell et al., 2017). Penurunan jumlah sel Leydig menyebabkan penurunan produksi hormon testosteron, sehingga proses spermatogenesis juga menurun.

Molekul $\alpha$-tokoferol memiliki efek yang menguntungkan karena sifat antioksidan yang larut dalam lipid. Molekul $\alpha$-tokoferol berperan sebagai pelindung utama terhadap stres oksidatif dan mencegah produksi peroksida lipid dengan pembilasan radikal bebas. Senyawa $\alpha$-tokoferol penting dalam mempertahankan integritas fisiologis testis, epididimis dan kelenjar aksesori yang berperan dalam spermatogenesis dan pematangan spermatozoa (Oda dan Maddawy, 
2012). Fungsi utama $\alpha$-tokoferol adalah sebagai chain-breaking antioksidan nonspesifik yang mencegah penyebaran radikal bebas. Molekul $\alpha$ tokoferol dapat menghambat transkripsi dan ekspresi dari gen CYP450 dan gen steroid dehydrogenase akibat induksi oleh dioxin terhadap aktivasi AhR. Senyawa $\alpha$-tokoferol dapat menurunkan competitive binding dari dioxin terhadap AhR dan protein pengikat hormon androgen. Upregulasi TCDD dari transkripsi dan ekspresi berbagai sitokrom-P450 melalui AhR dilawan oleh $\alpha$-tokoferol dengan menekan aktivitas produksi P450 hingga level mRNA (Singh et al., 2011).

Pada penelitian ini pemberian $\alpha$-tokoferol dengan dosis $140 \mathrm{mg} / \mathrm{kgBB} / \mathrm{hari}$ pada kelompok tikus yang dipapar TCDD meningkatkan kembali jumlah sel spermatogonium, spermatosit, spermatid, dan sel Leydig sehingga tidak berbeda nyata dibandingkan pada kelompok tikus normal (Tabel 1). Mekanisme perlindungan $\alpha$-tokoferol melalui kemampuannya dengan cepat dan efektif mengikat radikal peroxyl lipid sebelum serangan terjadi pada membran lipid testis dan sel spermatogenik. Senyawa $\alpha$-tokoferol merupakan sistem pertahanan non-enzimatik testis dalam mitokondria spermatozoa, dan mampu menghambat peroksidasi kerusakan testis (Chandra et al., 2010). Molekul $\alpha$-tokoferol dapat menghentikan peroksida lipid dengan mendonorkan satu atom hidrogen dari gugus $\mathrm{OH}$ ke lipid radikal peroxyl; dengan demikian, mereka menjadi kurang reaktif dan tidak merusak (Górnicka et al., 2019).

Senyawa $\alpha$-tokoferol merupakan antioksidan yang larut dalam lemak, sehingga lebih efektif sebagai pelindung terhadap stres oksidatif dan mencegah produksi lipid peroksida dengan cara menangkap radikal bebas (Capasso, 2013). Oleh karena itu, $\alpha$-tokoferol sangat penting dalam menjaga integritas fisiologis sel testis, epididymis, dan kelenjar aksesori yang memiliki peran penting dalam spermatogenesis (Kurutas, 2016), pemeliharaan dan kelangsungan hidup spermatid (Zubair, 2017). Senyawa $\alpha$-tokoferol berperan dalam mengatasi kerusakan oksidatif testis melalui kemampuannya untuk mengikat radikal peroksil lipid sebelum merusak membran lipid sel (Saddein et al., 2019). Molekul $\alpha$-tokoferol mengembalikan fungsi sel Leydig karena paparan TCDD melalui mekanisme berikut. Pertama, $\alpha$-tokoferol menekan AhR (Dietrich, 2016). AhR mengatur siklus sel, proliferasi sel, dan diferensiasi melalui interaksi dengan jalur pensinyalan lain, seperti reseptor estrogen $(\mathrm{ER} \alpha)$ dan reseptor androgen (AR) (Huang et al., 2016), sehingga memerangi efek merusak TCDD pada steroidogenesis sel Leydig. Kedua, sifat antioksidatif dari $\alpha$-tokoferol membersihkan ROS dan memodulasi regulasi transkripsi enzim antioksidan, meningkatkan ekspresi protein steroidogenic acute regulatory (StAR) (Banerjee et al., 2019). StAR mengantarkan kolesterol ke membran dalam mitokondria untuk diproses lebih lanjut di retikulum endoplasma sel Leydig untuk sintesis testosteron (Nozaki et al., 2018).

Pemberian $\alpha$-tokoferol dengan dosis yang lebih tinggi ( $259 \mathrm{mg} / \mathrm{kgBB} / \mathrm{hari})$ pada kelompok tikus yang dipapar TCDD menyebabkan jumlah sel spermatogonium, spermatid, dan sel Leydig lebih banyak, sedangkan jumlah sel spermatosit tidak berbeda nyata dibandingkan pada tikus normal (Tabel 1). Hasil ini sama dengan penelitian sebelumnya bahwa terjadi penurunan jumlah galur sel spermatogenik (spermatogonia, spermatosit, dan sel spermatid) dan sel Sertoli pada kelompok tikus yang dipapar oksidan. Selanjutnya terjadi peningkatan jumlah spermatosit dan sel spermatid pada pemberian $\alpha$ tokoferol pada tikus yang dipapar oksidan dibandingkan dengan hewan kontrol. (Saddein et al., 2019). Pemberian $\alpha$-tokoferol menyebabkan keseimbangan oksidan-antioksidan terjaga. Ketika terdapat kelebihan ROS hasil metabolisme fisiologis, maka gugus $-\mathrm{OH}$ dari $\alpha-$ tokoferol mendonorkan radikal hidrogen ke radikal lipid atau radikal lipid hidroperoksida. Pemutusan rantai reaksi peroksidasi lipid diikuti pembentukan radikal tokoferil atau tokotrienil yang stabil (Amorini et al., 2021). Mekanisme tersebut menyebabkan proses spermatogenesis berlangsung lebih baik daripada kondisi fisiologis normal.

\section{KESIMPULAN}

Pemberian $\alpha$-tokoferol dengan dosis 140 $\mathrm{mg} / \mathrm{kgBB} / \mathrm{hari}$ pada pada tikus putih (Rattus norvegicus) yang dipapar senyawa 2,3,7,8tetrachlorodibenzo-p-dioxin (TCDD) 700 
$\mathrm{ng} / \mathrm{kgBB} / \mathrm{hari}$ selama 20 hari efektif mempertahankan jumlah sel spermatogenik dan sel Leydig.

\section{DAFTAR PUSTAKA}

Amorini AM, Listorti I, Bilotta G, Pallisco R, Saab MW, Mangione R, Manca B, Lazzarino G, Tavazzi B, Lazzarino G, Bilotta P. 2021. Antioxidant-Based Therapies in Male Infertility: Do We Have Sufficient Evidence Supporting Their Effectiveness? Antioxidants (Basel) 10: 220.

Asadi N, Bahmani M, Kheradmand A, RafieianKopaei M. 2017. The Impact of Oxidative Stress on Testicular Function and the Role of Antioxidants in Improving it: A Review. J Clin Diagn Res. 11: IE01-IE05.

Banerjee B, Chakraborty S, Chakraborty P, Ghosh D, Jana K. 2019. Protective Effect of Resveratrol on Benzo(a)Pyrene Induced Dysfunctions of Steroidogenesis and Steroidogenic Acute Regulatory Gene Expression in Leydig Cells. Front Endocrinol. 10: 1-14.

Baskaran S, Finelli R, Agarwal A, Henkel R. 2021. Reactive oxygen species in male reproduction: A boon or a bane? Andrologia 53: e13577.

Capasso A. 2013. Antioxidant action and therapeutic efficacy of Allium sativum L. Molecules 18: 690-700.

Chandra AK, Chatterjee A, Ghosh R, Sarkar M. 2010. Vitamin E supplementation protect chromium (VI)-induced spermatogenic and steroidogenic disorders in testicular tissues of rats. Food Chem Toxicol. 48: 972-79.

Ciftci O, Duman AS, Turkmen NS, Taslidere A. 2018. Beta-glucan prevents toxic effects of $2,3,7,8$-TCDD in terms of oxidative and histopathological damage in heart tissue of rats. Braz J Pharm Sci. 54: 1-7.

Darbandi M, Darbandi S, Agarwal A, Sengupta P, Durairajanayagam D, Henkel R, Sadeghi MR. 2018. Reactive oxygen species and male reproductive hormones. Reprod Biol Endocrinol. 16: 87: 1-14.

Dietrich C. 2016. Antioxidant Functions of the Aryl Hydrocarbon Receptor. Stem Cells Int. 2016: 1-10.
Dirican EK, Kalender Y. 2012. Dichlorvosinduced testicular toxicity in male rats and the protective role of vitamins $\mathrm{C}$ and $\mathrm{E}$. Exp Toxicol Pathol. 64: 821-30.

Domínguez R, Pateiro M, Gagaoua M, Barba FJ, Zhang W, Lorenzo JM. 2019. A Comprehensive Review on Lipid Oxidation in Meat and Meat Products. Antioxidants 8: 1-31.

El-Gerbed MS, El-Saad AMA, Haussein AB. 2015. 2,3,7,8-tetrachloro-dibenzo-p-dioxin induced testicular toxicity in rats and the protective effect of quercetin: biochemical, histopathological and immunohistochemical studies. J Appl Pharm Sci. 5: 99-109.

Górnicka M, Ciecierska A, Hamulka J, Drywień ME, Frackiewicz J, Górnicki K, Wawrzyniak A. 2019. $\alpha$-Tocopherol Protects the Heart, Muscles, and Testes from Lipid Peroxidation in Growing Male Rats Subjected to Physical Efforts. Oxid Med Cell Longev. 2019: 1-13.

Guo W, Pan B, Sakkiah S, Yavas G, Ge W, Zou W, Tong W, Hong H. 2019. Persistent Organic Pollutants in Food: Contamination Sources, Health Effects and Detection Methods. Int J Environ Res Public Health 16: 1-29.

Huang B, Butler R, Miao Y, Dai Y, Wu W, Su W, Fujii-Kuriyama Y, Warner M, Gustafsson JA. 2016. Dysregulation of Notch and ER $\alpha$ signaling in AhR-/- male mice. Proc Natl Acad Sci. USA 113: 11883 8.

Jin M, Lou J, Yu H, Miao M, Wang G, Ai H, Huang Y, Han S, Han D, Yu G. 2018. Exposure to 2,3,7,8-tetrachlorodibenzo-pdioxin promotes inflammation in mouse testes: The critical role of Klotho in Sertoli cells. Toxicol Lett. 295: 134-43.

Kurutas EB. 2016. The importance of antioxidants which play the role in cellular response against oxidative/nitrosative stress: current state. Nutr J. 15: 1-22.

Listyorini L, Hernawati T, Suprayogi TW. 2021. Potensi madu pada peningkatan jumlah sel spermatogenik tikus (Rattus norvegicus) yang kekurangan nutrisi. Ovozoa 10: 12-7.

Meroni SB, Galardo MN, Rindone G, Gorga A, Riera MF, Cigorraga SB. 2019. Molecular Mechanisms and Signaling Pathways 
Involved in Sertoli Cell Proliferation. Front Endocrinol. 10: 224.

Ni FD, Hao SL, Yang WX. 2019. Multiple signaling pathways in Sertoli cells: recent findings in spermatogenesis. Cell Death Dis. 10: 541 .

Nozaki M, Haraguchi S, Miyazaki T, Shigeta D, Kano N, Lei XF, Kim-Kaneyama JR, Minakata H, Miyazaki A, Tsutsui K. 2018. Expression of steroidogenic enzymes and metabolism of steroids in COS-7 cells known as non-steroidogenic cells. Sci Rep. 8: 1-11.

O’Donnell L, Stanton P, de Kretser DM. 2017. Endocrinology of the Male Reproductive System and Spermatogenesis. In: Feingold KR, Anawalt B, Boyce A (Ed.) Endotext Internet. South Dartmouth (MA): MD Text.com, Inc.; 2000-. Available from: https://www.ncbi.nlm.nih.gov/books/NBK2 79031/

Oda SS, El-Maddawy ZKh. 2012. Protective effect of vitamin $E$ and selenium combination on deltamethrin induced reproductive toxicity in male rats. Experimental and Toxicologic Pathology 64: 813-19.

Oshchepkova E, Sizentsova Y, Wiebe D, Mironova V, Kolchanov N. 2020. MetaAnalysis of Transcriptome Data Detected New Potential Players in Response to Dioxin Exposure in Humans. Int J Mol Sci. 21: 7858 .

Perucatti A, Genualdo V, Colonna MA, Giannico F, Incarnato D, Lubrano-Lavadera G, Iorio C, Vonghia L, Caputi-Jambrenghi A, Iannuzzi L, Iannuzzi A. 2016. Chromosome instability in lymphocytes of Friesian cows naturally exposed to dioxins being raised close to a metallurgic factory area in southern Italy. Caryologia 69: 13340.

Plunk EC, Richards SM. 2020. EndocrineDisrupting Air Pollutants and Their Effects on the Hypothalamus-Pituitary-Gonadal Axis. Int J Mol Sci. 21: 1-24.

Redza-Dutordoir M, Averill-Bates DA. 2016. Activation of apoptosis signalling pathways by reactive oxygen species. Biochem Biophys Acta. 1863: 2977-92.

Saddein ET, Haghpanah SN, Nematollahi-
Mahani F, Seyedi, Ezzatabadipour M. 2019. Preventative Effects of Vitamin E on Testicular Damage and Sperm Parameters in the First-Generation Mice Pups due to Preand Postnatal Mancozeb Exposure. J Toxicol. 2019: 1-12.

Singh NP, Singh UP, Singh B, Price RL, Nagarkatti M, Nagarkatti PS. 2011. Activation of aryl hydrocarbon receptor (AhR) leads to reciprocal epigenetic regulation of FoxP3 and IL-17 expression and amelioration of experimental colitis. PloS One 6: e23522.

Ulfana I, Darsono R, Mulyati S. 2015. Boraks mengakibatkan penurunan jumlah sel spermatogonium dan sel sertoli pada gambaran histopatologi testis tikus putih (Rattus norvegicus). Ovoozoa 4: 1-4.

Wagner H, Cheng JW, Ko EY. 2017. Role of reactive oxygen species in male infertility. Arab J Urol. 16: 35-43.

Walker WH. 2011. Testosterone signaling and the regulation of spermatogenesis. Spermatogenesis 1: 116-20.

Wati WK, Wurlina W, Sarmanu S. 2014. Potensi vitamin $\mathrm{E}$ terhadap jumlah sel spermatogenik pada tikus yang terpapar 2,3,7,8-tetrachlorodibenzo-p-dioxin (TCDD). Vet Medika 7: 224-31.

Wurlina W, Mustofa I, Meles DK, Mulyati S, Putri DKSC, Suwasanti N. 2021. Administration of the $\alpha$-tocopherol for repairing testicle histological damage in rats exposed to dioxin. Thai J Vet Med. 51: 293301.

Yin HP, Xu JP, Zhou XQ, Wang Y. 2012. Effects of vitamin $E$ on reproductive hormones and testis structure in chronic dioxin- treated mice. Toxicol ind health 28: 152.

Zhou W, De Iuliis GN, Dun MD, Nixon B. 2018. Characteristics of the Epididymal Luminal Environment Responsible for Sperm Maturation and Storage. Front Endocrinol. 9: 1-13.

Zielinski ZA, Pratt DA. 2017. Lipid Peroxidation: Kinetics, Mechanisms, and Products. J Org Chem. 82: 2817-25.

Zubair M. 2017. Effects of dietary vitamin E on male reproductive system. Asian Pac J Reprod. 6: 145-50. 
Ainun Machmudia et al., 2021/Ovozoa 10: 74-79

Zubair M, Adrees A. 2019. Chapter 7. Dioxins and Furans: Emerging Contaminants of Air.
Open access peer-reviewed chapter. IntechOpen. 113-4. 